\title{
Juvenile - Mature Genetic Correlations in Pinus pinaster Ait. Under Different Nutrient x Water Regimes
}

\author{
By R. ZAS*, E. MerLo and J. FernÁNDEZ-LóPEZ
}

\begin{abstract}
Dpto. Producción Forestal, Centro de Investigacións Forestais e Ambientais de Lourizán. Apdo. 127, 36080 Pontevedra, Spain;
\end{abstract} phone: +34 986 805067; fax: +34 986 856420; E-mail: rzas.cifal@siam-cma.org.

(Received $6^{\text {th }}$ July 2004)

\begin{abstract}
Summary
Juvenile - mature (JM) correlations and selection efficiencies among one-year old Pinus pinaster seedlings and 8-yr field performance were analyzed in order to study the possibilities of early selection in the maritime pine breeding program in Galicia (NW Spain). Twenty four open-pollinated families from a first generation clonal seed orchard were grown in the greenhouse under two nutrient crossed with two water regimes. Several growth and dry mass traits were assessed 30 weeks after sowing and compared with field performance (height, diameter and volume) of four 8-yr-old progeny tests established in the coastal area of Galicia. Family mean correlations and genetic correlations were computed for each greenhouse trait, greenhouse treatment, field test site and field trait combination. Except for a few cases, most of the JM correlations were weak and in many cases negative. There was no detectable pattern of JM correlations regarding to combinations of greenhouse treatments and test site water availability and/or fertility. The large variation in the JM correlations for the same traits in different environments and sites (even changing sign in several cases) suggest a large influence of the genotype $x$ environment interaction in the JM estimations. Other possible causes of the weak JM correlations are discussed. Based on the results of this study it may be concluded that none of the combinations of trait and treatment included in this experiment can be recommended for incorporation into early testing in the Galician Pinus pinaster breeding program. Indications for further research to optimize an early selection procedure are included.
\end{abstract}

Key words: early selection, maritime pine, drought, nutrient availability, retrospective studies, greenhouse - field correlations.

\section{Introduction}

Maritime pine (Pinus pinaster Ait.) is the most important forest species in Galicia (NW Spain) where occupies nearly 400,000 ha. Improvement of maritime pine in the coastal area of Galicia has started in the 80's and has included phenotypic mass selection in wild stands based on growth, stem form and branching habit. Clonal seed orchards and first generation progeny tests of the phenotypic selections were established to select genetically superior families for reforestation and for further breeding purposes. As in any other tree breeding program, a reliable early selection method is highly desirable to increase the genetic gain per unit of time (WU, 1999) or to reduce the size and cost of the field tests by early culling of the worse families (Wu, 1998).

Important research has been carried out in recent years looking for a reliable procedure for early testing, including the selection of the best early traits (e.g. HARFOUCHE, 2003; KREMER et al., 1991; Kremer and XU, 1989; Williams, 1988) and the best environmental conditions (e.g. ERIKSSON et al., 1993; JoNsSON et al., 2000; KARLSSON et al., 2002; MARI et al., 2002; SONESson et al., 2001; 2002) that maximize the juvenile - mature (JM) correlations. In the case of maritime pine, three research

\footnotetext{
* to whom correspondence should be addressed.
}

lines have been developed in France. On one hand, early studies have been focused to find proper juvenile traits for early testing, including growth components (number and length of stem units, etc.), growth curves derived traits and parameters derived from multivariate analysis (KREMER and XU, 1989). Some growth components were found to be better predictors of mature performance than the composite trait (KREMER et al., 1991). On the other hand, early test studies have tried to increase the rate of maturation by growing the seedlings under accelerating growth conditions. Under normal conditions, $P$. pinaster shows free growth (simultaneous initiation and elongation of internodes) during the first growing season whereas predetermined growth is the main growth form in adult trees. Poor JM correlations between 1-yr-old seedlings and mature performance can be due to different genetic control of the free and cyclic growth (KREMER et al., 1991). Growth accelerating conditions induce the formation of a bud during the first growing season (generating cyclic growth) and, in average, resulted in better JM correlations than normal conditions (KREMER and Xu, 1989; Lascoux et al., 1992; 1993a; 1993b; NGUYen et al., 1995). More recently, HARFouche (2003) tried to improve the JM correlations by mimicking the summer drought in Landes (France), but the results of this experiment did not give any support to this hypothesis.

Climate in the coastal area of Galicia is typically Atlantic with high annual and summer precipitation, whereas in the interior area the summer drought becomes important, resulting in a more Mediterranean climate. Within each climatic area, maritime pine is usually planted over a wide range of soil fertilities, from fertile abandoned agricultural lands to skeletal forest soils. The stability of the breeding material to the water and nutrient availabilities is, thus, a critical factor in order to use the improved material all around Galicia. Previous research in the greenhouse have shown that family $\mathrm{x}$ water and family $\mathrm{x}$ nutrient interactions in one-yr-old $P$. pinaster seedlings are quantitatively important and should not be ignored (ZAS and FERNÁNDEZ-LóPEZ, under revision). However, this study was performed on very young seedlings in very artificial environments, and the results may be not extrapolable to mature field conditions.

The objective of the present study was to estimate JM genetic correlations between one year old traits in the greenhouse and 8-yr field performance as a tool to explore the potential of early testing in the Galician maritime pine breeding program. Open-pollinated families were grown under different water and nutrient availabilities for selecting the optimum early growth conditions and the optimum early trait that maximize the JM correlations.

\section{Material and Methods}

\section{Material}

The material used in this study consisted in a subset of the first generation open-pollinated families of the maritime pine 
Table 1. - Description of the field trials.

\begin{tabular}{|c|c|c|c|c|}
\hline \multirow[t]{2}{*}{ Variable } & \multicolumn{4}{|l|}{ Sites } \\
\hline & A & $\mathrm{B}$ & $\mathrm{C}$ & $\mathrm{L}$ \\
\hline Annual precipitation (mm) & 1760 & 1730 & 1106 & 1202 \\
\hline Summer precipitation (mm) & 143 & 186 & 118 & 93 \\
\hline Annual mean temperature $\left({ }^{\circ} \mathrm{C}\right)$ & 12.6 & 13.1 & 12.6 & 11.3 \\
\hline Altitude (m) & 525 & 300 & 530 & 700 \\
\hline Slope $(\%)$ & 24.9 & 26.8 & 5.2 & 17.6 \\
\hline Soil depth $(\mathrm{cm})$ & 84.4 & 47.0 & 60.9 & 59.5 \\
\hline Overall height mean at age $8(\mathrm{~m})$ & 5.1 & 4.9 & 5.6 & 4.4 \\
\hline \multicolumn{5}{|l|}{ Superficial soil characteristics } \\
\hline $\mathrm{pH}(\mathrm{H} 2 \mathrm{O})$ & 4.6 & 4.5 & 4.6 & 4.6 \\
\hline $\mathrm{C}: \mathrm{N}$ ratio & 15.1 & 15.0 & 15.2 & 15.4 \\
\hline Total $\mathrm{N}\left(\mathrm{g} \mathrm{kg}^{-1}\right)$ & 6.5 & 7.4 & 5.6 & 5.1 \\
\hline P Olsen $\left(\mathrm{mg} \mathrm{kg}^{-1}\right)$ & 4.1 & 3.5 & 2.4 & 4.5 \\
\hline Exchangeable $\mathrm{K}\left(\mathrm{mg} \mathrm{kg}^{-1}\right)$ & 76.7 & 66.3 & 61.1 & 76.7 \\
\hline Exchangeable $\mathrm{Ca}\left(\mathrm{mg} \mathrm{kg}^{-1}\right)$ & 27.3 & 55.3 & 12.7 & 28.0 \\
\hline Exchangeable $\mathrm{Mg}\left(\mathrm{mg} \mathrm{kg}^{-1}\right)$ & 48.0 & 48.4 & 12.1 & 17.7 \\
\hline Sand (\%) & 81.9 & 83.6 & 79.5 & 73.8 \\
\hline Silt (\%) & 2.9 & 4.8 & 3.6 & 5.7 \\
\hline Clay $(\%)$ & 15.2 & 11.6 & 16.8 & 20.5 \\
\hline
\end{tabular}

breeding program in Galicia (NW Spain). Twenty four open-pollinated families were randomly selected from the Sergude clonal seed orchard $\left(42^{\circ} 49^{\prime} \mathrm{N} ; 8^{\circ} 27^{\prime} \mathrm{W}\right)$. All plus trees in this orchard were selected for superior growth, stem form and branch characteristics within the provenance '1a, Noroeste Litoral' (ALÍA et al., 1996).

\section{Field trials}

The selected 24 half-sib families are represented in 2-4 progeny tests established in 1994 and 1995: Asneves (site A), Bamio (site B), Cortegada (site C) and Lalín (site L). Ten out of the 24 families are represented in all the four sites, whereas five and nine families are just represented in three and two sites, respectively. Site characteristics are presented in Table 1. Sites are included within the RIU (Region of Identification and Utilization of forest reproductive material (GARCíA et al., 2001)) number 1 which constitute, a priori, the breeding area for the selected material. The sites have Atlantic climate characterized by relative high annual precipitation and low summer drought. Sites C and L show a slight Mediterranean influence with lower annual and summer precipitation (Table 1). All sites have acid and coarse textured soils, relatively high levels of total nitrogen, and very low levels of phosphorus. Exchangeable cations are relatively low, especially in sites $\mathrm{C}$ and $\mathrm{L}$. Despite the lower precipitation and fertility, site C shows the highest overall mean height at age 8 . Site L, which shows the highest altitude, was the worse site.

All the four plantations follow a randomized complete block design with 10 replications of 5 tree-row-plots with $3 \times 3 \mathrm{~m}$ spacing. Tree height $\left(\mathrm{H}_{8}\right)$ and breast-height diameter $\left(\mathrm{DBH}_{8}\right)$ were measured in all trees at age 8 from plantation. A stem volume index was calculated for each tree as $\mathrm{V}_{8}=\mathrm{H}_{8} \cdot \mathrm{DBH}_{8}{ }^{2}$.

\section{Greenhouse experiment}

Seeds from these 24 open-pollinated families were cultivated in the greenhouse for one growth period (30 weeks) under different water and nutrient regimes. The seeds were sown on $7 x$ $7 \times 8 \mathrm{~cm}$ pots filled with perlite and covered with a thin layer of sand. Seven weeks after sowing, the successfully germinated pots were placed following a split-plot design with four blocks. The four treatments ( 2 nutrient $\times 2$ water regimes) were the whole plots and the maritime pine families were the split-plots. Each family was represented by 5 seedlings arranged in 5 subblocks within each treatment-block combination. Due to poor germination of a few families the total number of seedlings per family and treatment varied between 15 and 20 with an average of 19.2 .

Two fertilization treatments crossed with two irrigation regimes were applied together by subirrigation for 23 weeks. The two different irrigation regimes were the well watered treatment (water high, w:H) with watering to field capacity every day, and the drought treatment (water low, w:L) with a periodical drought. Drought was regulated by measuring the loss of water content of ten randomly selected seedlings per treatment-block combination. These control seedlings were weighed every day or every second day to estimate the water content. The drought treatment seedlings were watered to field capacity when the water weight reached $40-20 \%$ of the field capacity weight, increasing the drought intensity with time (Figure 1). The control seedlings were weighed again after irrigation. As it can be seen in Figure 1, the water content at field capacity decreased with time due to a degeneration of the water retention capacity of the substrate. The abnormal watering of the w:L-n:H treatment in mid august was due to a breakdown in the fog-press system that let to an unplanned watering of some blocks of this treatment.

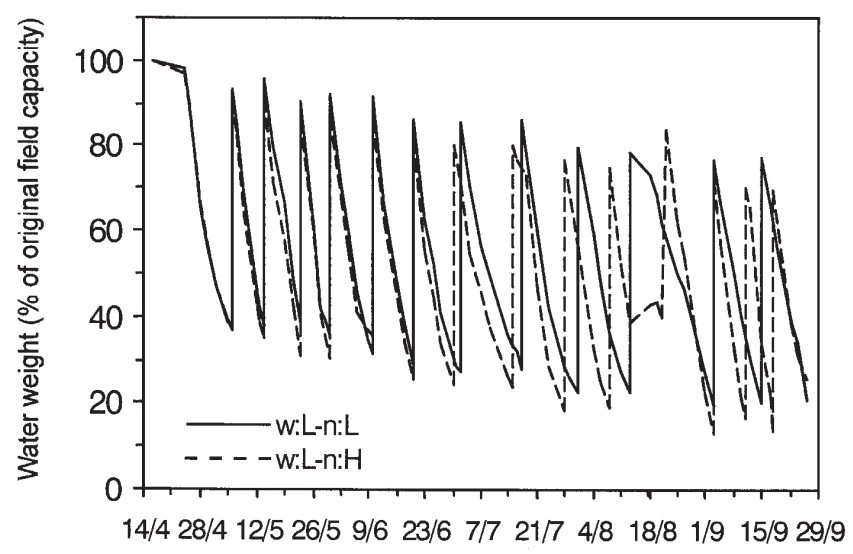

Figure 1. - Evolution of the mean water weight for the two drought treatments (low water and nutrient supply (w:L-n:L) and low water and high nutrient supply (w:L-n:H)) during the juvenile experiment.

Within each irrigation regimen, two different nutrient solutions were used, the free access treatment (nutrient high, n:H) and the deficiency treatment (nutrient low, n:L). The n:H treatment consisted of a complete nutrient solution (macroelement proportions by weight $100 \mathrm{~N}: 20 \mathrm{P}: 70 \mathrm{~K}: 7 \mathrm{Ca}: 9 \mathrm{Mg}: 9 \mathrm{~S}$ and micronutrients) containing $100 \mathrm{mg} \mathrm{N} \mathrm{Kg}{ }^{-1}$. The low nutrient availability treatment $(n: L)$ was a 10 times dilution of the $n: H$ solution.

Seedlings were harvested 23 weeks after treatments have started. Total height $(\mathrm{H})$, root collar diameter (D) and dry weights $\left(80^{\circ} \mathrm{C}, 24 \mathrm{~h}\right)$ of shoots (SDW) and roots (RDW) were measured. The total dry weight $(\mathrm{TDW}=\mathrm{SDW}+\mathrm{RDW})$, the vol- 
ume index $\left(\mathrm{V}=\mathrm{H} \cdot \mathrm{D}^{2}\right)$, the root/shoot ratio $(\mathrm{RSR}=\mathrm{RDW} / \mathrm{SDW})$ and the height/diameter ratio (HDR) were also calculated.

\section{Analysis}

The significance of the correlations between the early traits in the greenhouse and the mature traits in the field was estimated by Pearson correlation between family means using the SAS corr procedure (SAS-INSTITUTE, 1990).

The juvenile - mature genetic correlations were estimated as

$$
r_{G x y}=\frac{r_{x y}}{\sqrt{h_{x}^{2} h_{y}^{2}}}
$$

where $r_{x y}$ is the Pearson correlation of family means and $h^{2}$ and $h_{y}^{2}$ are the family heritabilities of the juvenile and mature trait, respectively. Heritabilities were calculated on a single treatment (or single site) basis and were reported in ZAS and FERNÁNDEZ-LóPEZ (under revision) for the juvenile traits, and in ZAS et al. (2004) for the field traits.

To test the efficacy of early family selection two selection alternatives were considered (ADAMs et al., 2001): single-stage and two-stage early family selection. In single stage selection, selections are carried out based on juvenile performance alone whereas in two-stage selections, screening at the juvenile stage is used to identify and cull poor-performing genotypes prior to the establishment of field trials. Final selections are conducted based on mature field traits.

The relative efficiency of early single stage selection $\left(\mathrm{RESS}_{\mathrm{xy}}\right)$ was calculated as a gain ratio of the indirect selection in the greenhouse to the direct field trial selection:

$$
\operatorname{RESS}_{x y}=\operatorname{SSR}_{y} / R_{y}
$$

where $S S R_{y}$ is the correlated response in the mature trait of interest from selection of families at the seedling stage and $R_{y}$ is the expected response when the field trait is selected directly:

$$
\begin{gathered}
S S R_{y}=i h_{x} h_{y} r_{G x y} \sigma_{y} \\
R_{y}=i h_{y}^{2} \sigma_{y}
\end{gathered}
$$

where $i$ is the intensity of juvenile selection, $h_{x}$ and $h_{y}$ are the square-roots of the family heritabilities for the juvenile trait $x$ and the mature trait $y, r_{G x y}$ is the juvenile mature genetic correlation between both traits, and $\sigma_{y}$ is the phenotypic standard deviation among family means for the field trait.

Assuming the same intensity of selection at both ages:

$$
\operatorname{RESS}_{x y}=\frac{h_{x}}{h_{y}} r_{G x y}
$$

The relative efficiency of two-stage selection $\left(\right.$ RET $\left.S_{x y}\right)$ compared to single-stage field selection is:

$$
\operatorname{RETS}_{x y}=\frac{T S R_{y}}{R_{y}}
$$

where $T S R_{y}$ is the expected response in the field trait y from two-stage selection and is calculated as (see ADAMs et al., 2001):

$$
T S R_{y}=i_{1} r_{x y} \sigma_{y}+i_{2} \sigma_{y}\left[\frac{h_{y}^{2}-r_{x y}^{2} H}{\sqrt{1-r_{x y}^{2} H}}\right]
$$

where $i_{1}$ and $i_{2}$ are the intensities of selection at the juvenile and mature stages respectively, and $H=i_{1}\left(i_{1}-x_{1}\right)$, where $x_{1}$ is the value of trait $x$ at the point of truncation of selection in the juvenile stage, expressed in standard deviations from the mean. The first term of the last expression $\left(i_{1} r_{x y} \sigma_{y}\right)$ is the gain expected from selection in the early test, whereas the remain- der is the gain expected when mature selection is practiced in the truncated population on the field test.

To compare the efficiency of two-stage selections among traits and treatments we considered 200 families to be tested, $25 \%$ of them are culled in the greenhouse on the basis of early traits, and $20 \%$ (40 families) are finally selected in the field trials.

\section{Results}

The genetic parameters of the juvenile traits and the field traits were presented elsewhere (ZAS and FERNÁNDEZ-LÓPEZ, under revision; ZAS et al., 2004). Family heritability estimates for growth and biomass traits were high (0.4-0.7) in individual treatments (ZAS and FERNÁNDEZ-LóPEZ, under revision). Family $\mathrm{x}$ water and family $\mathrm{x}$ nutrient interactions were quantitatively important, reducing the heritability estimates for the combined treatments analysis. In the field traits, family heritability for $\mathrm{H}_{8}, \mathrm{DBH}_{8}$ and $\mathrm{V}_{8}$ varied between 0.2 and 0.6 for individual site analyses (ZAS et al., 2004). Total height was the most heritable trait. The genotype $\mathrm{x}$ site interaction was relatively important, especially for $\mathrm{V}_{8}$ (ZAS et al., under revision). The ratio of interaction to family variance component varied between 100 and $200 \%$. The interaction was mainly due to a few highly interactive families that may be particularly sensitive to environmental variation.

A total of 23 out of 384 estimated correlation coefficients between family means were significant $(\mathrm{p}<0.05)$ (Table 2).

\begin{tabular}{|c|c|c|c|c|}
\hline \multirow[t]{2}{*}{ Treatment $^{1}$} & \multicolumn{4}{|l|}{ Sites } \\
\hline & A & B & $\mathrm{C}$ & $\mathrm{L}$ \\
\hline w:L-n:L & $2(3)$ & $1(3)$ & $1(5)$ & $1(1)$ \\
\hline w:L-n:H & & $1(2)$ & & \\
\hline w:H-n:L & $1(3)$ & $3(5)$ & $6(11)$ & \\
\hline w:H-n:H & & $7(8)$ & & \\
\hline
\end{tabular}
Most of the significant correlations were found for site B and C, especially with well watered treatments.

Table 2. - Number of significant $(\mathrm{p}<0.05)$ (and $\mathrm{p}<0.10$ in parentheses) family mean correlations between field growth data $\left(\mathrm{H}_{8}, \mathrm{DBH}_{8}\right.$ and $\left.\mathrm{V}_{8}\right)$ in four trials with juvenile data from 4 irrigation - fertilization treatments in greenhouse.

1 w:L-n:L: periodical drought and restricted access to nutrients, w:L-n:H: periodical drought and high nutrient availability, w:H-n:L: well watered and restricted access to nutrients, w:H-n:H: well watered and high nutrient availability.

Genetic correlations between greenhouse traits and volume at field were highly variable (Table 3 ). The genetic correlations were in the range -1 to 1 , with some cases exceeding these values due to low family heritability of one or both traits. There was not any clear trend. Notable were the negative genetic correlations for almost all traits and treatments in sites A, B and $\mathrm{L}$ in contrast to positive correlations in site C. Height, volume and root shoot ratio $(\mathrm{RSR})$ significantly correlated $(\mathrm{p}<0.05)$ with $\mathrm{V}_{8}$ in several cases. Despite the relatively higher genetic correlations observed in site $\mathrm{B}$, the correlation of family means was significant $(\mathrm{p}<0.05)$ only for height in the w:H-n:H treatment. This may be due to the lower number of families (13) common to the greenhouse and field test for site B in relation to the other sites (17-22). When considering all sites together, the only significant genetic correlation was obtained for RSR measured in the w:L-n:L treatment. Correlations with diame- 
Table 3. - Estimates of genetic correlations between greenhouse traits and stem volume in field traits $\left(\mathrm{V}_{8}\right)$.

\begin{tabular}{|c|c|c|c|c|c|c|}
\hline \multirow[t]{2}{*}{ Treatment } & \multirow[t]{2}{*}{ Trait } & \multicolumn{5}{|c|}{ Field Trials } \\
\hline & & A & B & $\mathrm{C}$ & $\mathrm{L}$ & ALL \\
\hline \multirow[t]{8}{*}{ w:L-n:L } & D & -0.26 & 0.42 & 0.42 & 0.13 & 0.26 \\
\hline & $\mathrm{H}$ & $-0.96^{*}$ & $-1.39^{\mathrm{kg}}$ & 0.69 & -0.45 & -0.32 \\
\hline & V & -0.41 & 0.21 & $0.68^{x}$ & 0.16 & 0.30 \\
\hline & HDR & -0.25 & -0.89 & 0.39 & -0.18 & -0.05 \\
\hline & RDW & -0.57 & -0.74 & -0.07 & -0.38 & -0.32 \\
\hline & RSR & -0.27 & -0.93 & $-0.81^{*}$ & -0.66 & $-0.76^{*}$ \\
\hline & SDW & -0.53 & 0.12 & 0.68 & 0.11 & 0.26 \\
\hline & TDW & -0.62 & -0.33 & 0.34 & -0.14 & -0.02 \\
\hline \multirow[t]{8}{*}{ w:L-n:H } & $\mathrm{D}$ & -0.42 & 0.00 & 0.24 & -0.63 & -0.23 \\
\hline & $\mathrm{H}$ & 0.07 & -0.78 & 0.70 & -0.23 & 0.29 \\
\hline & V & -0.27 & -0.27 & 0.49 & -0.39 & 0.00 \\
\hline & HDR & 0.48 & -1.11 & 0.62 & -0.07 & 0.36 \\
\hline & RDW & -0.26 & -0.14 & 0.23 & 0.07 & 0.00 \\
\hline & RSR & -0.13 & 1.04 & 0.38 & 1.00 & 0.36 \\
\hline & SDW & -0.64 & -1.08 & 0.31 & -0.47 & -0.22 \\
\hline & TDW & -0.54 & -0.83 & 0.30 & -0.31 & -0.16 \\
\hline \multirow[t]{8}{*}{ w:H-n:L } & $\mathrm{D}$ & $-0.73^{\text {n }}$ & -0.04 & $0.66^{\text {a }}$ & -0.75 & 0.07 \\
\hline & $\mathrm{H}$ & -0.01 & -0.85 & $0.93^{*}$ & -0.17 & 0.48 \\
\hline & V & -0.53 & -0.25 & $0.84^{*}$ & -0.58 & 0.25 \\
\hline & HDR & 0.82 & -0.96 & 0.38 & 0.42 & 0.46 \\
\hline & RDW & -0.53 & $-1.19^{\not A}$ & 0.58 & -0.50 & 0.02 \\
\hline & $\mathrm{RSR}^{1}$ & - & - & - & - & - \\
\hline & SDW & -0.53 & -0.91 & $0.83^{\mathrm{x}}$ & -0.21 & 0.10 \\
\hline & TDW & -0.51 & -1.02 & $0.67^{\text {D }}$ & -0.34 & 0.06 \\
\hline \multirow[t]{8}{*}{ w:H-n:H } & D & -0.18 & -0.57 & 0.07 & -0.50 & -0.12 \\
\hline & $\mathbf{H}$ & 0.19 & $-1.77^{*}$ & 0.44 & 0.29 & 0.30 \\
\hline & V & -0.12 & -0.97 & 0.35 & -0.28 & 0.08 \\
\hline & HDR & 0.38 & -0.32 & 0.25 & 0.54 & 0.34 \\
\hline & RDW & -0.25 & -1.36 & 0.32 & -0.20 & 0.12 \\
\hline & RSR & 0.48 & -0.90 & 0.19 & -0.40 & 0.51 \\
\hline & SDW & -0.46 & -0.91 & 0.41 & -0.31 & 0.03 \\
\hline & TDW & -0.43 & -0.97 & 0.40 & -0.30 & 0.05 \\
\hline
\end{tabular}

*, significant at $\mathrm{p}<0.05$ and $\mathrm{p}<0.10$ for family mean correlation, respectively.

${ }^{1}$ No genetic correlation calculated due to null family heritability.

ter and height data from the field trials (data not presented) showed the same trend than those for volume.

The relative efficiency of early selection is presented for site $\mathrm{C}$ in Table 4. The single stage selection was highly efficient for those traits and treatments that showed significant JM correlations, i.e. $\mathrm{H}$ and $\mathrm{V}$ in w:H-n:L and RSR in w:L-n:L. Relatively high values were also observed for other traits that showed correlations of family means near significance $(p<0.10)$. It is noteworthy that the relative efficiency of two-stage selection for the site $\mathrm{C}$ was near $100 \%$ in almost all cases.

\section{Discussion}

Except some few cases, all the JM correlations were weak and in many cases negative. The total number of significant family mean correlations was 23 out of 384 (Table 2), which is so low $(6 \%)$ that random reasons could explain their occurrence. However, the JM correlations between the w:H-n:L treatment and the site $\mathrm{C}$ and between the w:H-n:H and site $\mathrm{B}$ were higher, and random reasons alone may be not the only cause. We did not found any climatic and/or edaphic particularity (Table 1) of these sites that could explain these significant
Table 4. - Relative efficiency of early selection for volume at age 8 in the site $\mathrm{C}$ based on single stage (RESS) or two-stages (RETS ${ }^{1}$ ) selection.

\begin{tabular}{|c|c|c|c|c|c|c|c|c|}
\hline \multirow[t]{2}{*}{ Trait } & \multicolumn{2}{|c|}{ w:L-n:L } & \multicolumn{2}{|c|}{ w:L-n:H } & \multicolumn{2}{|c|}{ w:H-n:L } & \multicolumn{2}{|c|}{ w:H-n:H } \\
\hline & RESS & RETS & RESS & RETS & RESS & RETS & RESS & RET \\
\hline D & 0.47 & 0.9 & 0.22 & 0.94 & $0.76^{k x}$ & 1.02 & 0.08 & 0.9 \\
\hline $\mathrm{H}$ & 0.74 & 1.02 & 0.67 & 1.00 & $1.04^{*}$ & 1.03 & 0.46 & 1.0 \\
\hline$\nabla$ & $0.80^{a}$ & 1.04 & 0.51 & 0.99 & $1.02 *$ & 1.02 & 0.37 & 0.97 \\
\hline HDR & 0.42 & 0.97 & 0.42 & 0.98 & 0.38 & 0.97 & 0.29 & 0.95 \\
\hline RDW & -0.07 & 0.86 & 0.28 & 0.95 & 0.66 & 1.00 & 0.30 & 0.9 \\
\hline RSR & $-0.92 *$ & 0.67 & 0.32 & 0.96 & - & - & 0.11 & 0.9 \\
\hline SDW & 0.71 & 1.05 & 0.34 & 0.96 & $0.84^{x}$ & 1.02 & 0.43 & 0.9 \\
\hline TDW & 0.35 & 0.97 & 0.35 & 0.96 & $0.78^{\sharp}$ & 1.02 & 0.43 & 0.98 \\
\hline
\end{tabular}

* and denotes significance of family mean correlations at 5 and $10 \%$, respectively.

${ }^{1}$ In two-stages selection, $25 \%$ of the families are culled at the early stage on the basis of the early traits. The remaining families are tested in the field and final selections (20\%) are conducted on the basis of 8-yr traits. We assumed an starting number of 200 families, of which 150 are planted in the field and 40 families are finally selected at field.

correlations. There was not detectable pattern of JM correlations among the combinations of greenhouse treatment and test site water availability and/or fertility. These discouraging results are not surprising. Poor JM correlations between 1-yr old traits and field performance were also observed in many species (ABRAITIS et al., 1998; JANSSON et al., 1998; KARLSSON et al., 2002; MARI et al., 2002; SONESSON et al., 2001; 2002) and also in P. pinaster (HARFOUCHE, 2003). However, there are also many examples of good JM correlations with 1-yr old traits (ADAMs et al., 2001; BRIDGWATER and MCKEAND, 1997; JoNsSON et al., 2000). Inconsistent results were even observed in different provenances of the same species. In loblolly pine (Pinus taeda L.) strong correlations were observed for Texas families between field performance and 1st year shoot biomass traits in the greenhouse (LOWE and VAN-BUIJTENEN, 1989; WAXLER and VAN-BuiJTENEN, 1981), whereas in North Carolina provenances these JM correlations were weak (Li et al., 1991; WiLLIAMS, 1987).

Several reasons could be responsible of the low JM correlations in our study. Among them we detach the followings:

1) The lack of JM correlation between $1^{\text {st }}$ season height growth and later growth in $P$. pinaster families was explained by KREMER and XU (1989) to be due to different height growth patterns at both ages (free growth in the first season versus fixed growth in older trees). Similar conclusion was attained by Wu et al. (1997) in lodgepole pine (Pinus contorta ssp. latifolia Englm.) and Williams (1987) in loblolly pine. Significant positive JM correlations were observed for second year traits but not for first season traits in both studies. LASCOUX et al. (1993a) also found that consistency of phytotron and field rankings in $P$. pinaster families improved after the first bud set. These authors suggested that seedlings must attain a minimum development stage (transition from free growth to cyclic growth) before juvenile traits become a reliable selection criteria. This hypothesis bear to try to improve JM correlations by enhancing the expression of cyclic growth in the first growth season (produced after the formation of the apical bud) using 
growth accelerating conditions (LASCOUX et al., 1992; 1993a; WiLLIAMs, 1988).

2) Extreme suboptimal early test environments could reduce the JM correlations with field performance. Treatments were design to analyze the stability of the breeding material in relation to the water and nutrient availabilities, and extreme levels (very high and very low nutrient and water availabilities) for each factor were used. The resulting environmental conditions were probably very different from field natural conditions where rarely only one factor is limiting.

3) Several retrospective studies have found that JM correlations between growth chamber traits and field performance became stronger with increasing age of the field trial (ABRAITIS et al., 1998; ERIKSSON et al., 1993; JoNSSON et al., 2000). The weak correlations at young ages (ages 10 and 13) in these studies were attributed to nongenetic influences on growth during the phase of establishment. Postplanting stress in our field trials was very important because seedlings were pot-bound at planting due to a too long nursery period for the small container used (superleach, $125 \mathrm{cc}$ ). Pot-binding resulted in root deformations and poor stability of the seedlings, inducing stem leaning and low straightness (ZAS et al., 2004), and probably affecting shoot growth and, thus, JM correlations. In concordance with this idea, mean JM correlations between greenhouse growth traits and dry weights in the w:H-n:L treatment and height in site $\mathrm{C}$, where three height measurements were available, increased from 0.5 at ages 3 and 5 to 0.9 at age 8 .

4) The large variation in the JM correlations for the same traits in different treatments and sites (Table 3) suggest a large impact of the genotype $\mathrm{x}$ environment $(\mathrm{G} \times \mathrm{E})$ interaction in the JM correlation estimations. In the field trials, the $\mathrm{G} \times \mathrm{E}$ interaction was significant for the three growth traits $\left(\mathrm{H}_{8}\right.$, $\mathrm{DBH}_{8}$ and $\mathrm{V}_{8}$ ) with ratios of interaction to family variance components varying between 100 and 200\% (ZAS et al., under revision). In the greenhouse experiment, family $x$ water and family $x$ nutrient interactions were quantitatively important for almost all traits (ZAS and FERNÁNDEZ-LÓPEZ, under revision). Among all the greenhouse traits, height showed the lowest interaction and, thus, appeared as the best early trait. The impact of the GXE interaction was also considered as a cause of poor JM correlation in P. contorta (WU et al., 1997), P. sylvestris L. (SonESSON et al., 2001) and Pinus radiata D. Don (MATHESON et al., 1995). Wu et al. (1997) remarked that early selection should be used with caution when mature tests show $\mathrm{G} \times \mathrm{E}$ interaction.

5) The GxE interaction in both the greenhouse experiment and the field was due to a few interactive families especially sensitive to environmental variation (ZAS and FERNÁNDEZLÓPEZ, under revision; ZAS et al., under revision). If these interactive families are removed from the breeding population, the $\mathrm{G} \times \mathrm{E}$ became not significant. Thus, the selection of the families used to estimate the JM correlations would probably have an important influence in these estimations. It can be expected that higher JM correlation can be achieved if stable families are used. However, in the present study, where families were randomly selected, the stability parameter (ecovalence, WRICKE, 1962) estimated in the greenhouse was not significantly correlated with the same parameter estimated in the field (data not presented). Moreover, the JM correlations did not improve when the most interactive families were removed from the analysis.

6) The seeds used in the field tests were collected when the seed orchard was too young and not all the clones flowered. Pollination was restricted to those clones that early shed pollen. Conversely, the seeds used in the greenhouse experi- ment were collected several years after when all clones where shedding pollen. Different pollination patterns may have influenced the JM correlation estimates.

One of the main goals of this study was to find out the best traits and the best environmental conditions to use in a reliable early selection strategy. However, our results were inconclusive and it was difficult to determine which trait and treatment generated the best JM correlations. Nevertheless, growth traits, especially $\mathrm{H}$, appeared as a better early trait than dry masses. Despite heritability estimates were similar, the $\mathrm{G} \times \mathrm{E}$ interaction for growth traits was lower than for dry masses (ZAS and FERNÁNDEZ-LÓPEZ, under revision) and the JM correlations with field performance were slightly higher (Table 3). In other retrospective studies results are, again, very variable. Growth traits showed higher JM correlations with field performance in many cases (e.g. ABRAITIS et al., 1998; ADAMS et al., 2001; Li et al., 1991; Wu et al., 1997) but in other cases dry weights were better predictors of mature performance (e.g. HARFOUChe, 2003; KARLSSON et al., 2002; MATHESON et al., 1995). The use of growth component traits, growth curve derived traits or growth traits assessed after the first growing season as early selection traits should be further investigated. Some of them have been shown to be good early selection traits in other $P$. pinaster breeding populations (KREMER and $\mathrm{XU}$, 1989; LASCOUX et al., 1993a).

In relation to the early environments, the number of significant correlations was higher in the well watered treatments than in the drought treatments (Table 2) but this result must be used with care because the significant JM correlations were of different sign for different field tests (Table 3). The negative JM correlations with sites A, B and L but not with site C are hard to explain. Other authors have also found significant negative JM correlations, especially with traits related to the root dry weight (HARFOUCHE, 2003; KARLSSON et al., 2002; SONESSON et al., 2001). Some of the reasons given to explain the weak JM correlation may also explain these negative correlations but, probably, the $\mathrm{G} \times \mathrm{E}$ interaction among the extreme treatments in the greenhouse is the most important. Extreme early conditions that are highly limiting generally result in higher $\mathrm{G} \times \mathrm{E}$ interaction effects and thus reduce JM correlations (ERIKSSON et al., 1993; Li et al., 1991). Field conditions are a compendium of multiple factors, with complex interactions among them. The limiting factor may be difficult to isolate and the water and nutrient stress simulated in the greenhouse may not reflect the real environmental conditions in the field. HARFOUCHE (2003) reached similar conclusions in his retrospective study with $P$. pinaster families grown under two different water regimes. Intermediate water and nutrient conditions should be tested to find out the best environmental conditions for early testing in the Galician P. pinaster breeding program.

Regardless the low JM correlation, the efficiency of two-stage early selection was very high (Table 4). The possibility of early culling the worse families prior to field test establishment, and thus reduce the size and cost of the field tests, is very interesting in Galicia where high quality and homogeneous sites for progeny test establishment are difficult to find. Because $P$. pinaster is planted with one-yr-old seedlings, early test based on first season traits would avoid any unnecessary delay in field planting, and the same material used in the early test can serve as the stock for field planting. As observed by ADAMS et $a l$. (2001), family means correlations as low as 0.3 or 0.4 generated high relative efficiencies of two-stage early selection. However, our results were inconsistent among treatments and sites and further research is needed to find out the best $1^{\text {st }}$ growing season traits and the best growth controlled conditions in the greenhouse that improve JM correlations. 


\section{Acknowledgements}

This study was supported by the INIA project RTA2-109. We thank Agustin Quintairós, Sonia QueIMADELos and ViCENTE VIDAL of the C.I.F.A Lourizán and the students CRISTINA FERNÁNDEZ, VICTOR BARRO and PATRICIA MARTINS for taking care of the seedlings during the greenhouse experiment and for their help in assessments. The series of field trials was established by the co-ordination of G. VEGA. Nursery and plantation was under the supervision of MARIANO ARNEDO. We thank RICARDO Ferradás, Agustin Quintairós, Sonia Queimadelos, Marisa Blanco, Pilar Soto and Maribel Juncal of the C.I.F.A. Lourizán and the students DAVId DíAZ, Elías CABRERA and Marga GARCía for field assessments. Dr. LUIS SAMPEDRO is also acknowledged for his helpful suggestions on the manuscript.

\section{References}

Abraitis, R., Norell, L. and ERIKsson, G. (1998): Retrospective studies on nitrogen response of Pinus sylvestris L. For Genet. 5(1): 39-45.

Adams, W. T., Aitken, S. N., Joyce, D. G., Howe, G. T. and VarGAS-HERNÁNDEZ, J. (2001): Evaluating efficacy of early testing for stem growth in coastal Douglas-fir. Silvae Genet. 50(3-4): 167-175.

Alía, R., Martin, S., De Miguel, J., Galera, R., Agúndez, D., Gordo, J., Catalán, G. and Gil, L. (1996): Las regiones de procedencia de Pinus pinaster Ait. OA de Parques Nacionales. DGCONA, Madrid, 75 p.

Bridgwater, F. E. and McKeand, S. E. (1997): Early family evaluation for growth of loblolly pine. For. Genet. 4(1): $51-58$.

Eriksson, G., Jonsson, A., Dormling, I., Norell, L. and StenER, L. G. (1993): Retrospective early tests of Pinus sylvestris L. seedlings grown under five nutrient regimes. For. Sci. 39(1): 95-117.

García, J. M., De-Miguel, J., Alía, R. and Iglesias, S. (2001): Regiones de Identificación y Utilización de material forestal de reproducción. Ministerio de Medio Ambiente. Serie Cartográfica, Madrid, $293 \mathrm{p}$.

HARFOUCHE, A. (2003): Retrospective early test for adult vigor of Pinus pinaster families grown under two water regimes. Implications for early selection. Ann. For. Sci. 60(6): 539-547.

JANSSON, G., Jonsson, A. and ERIKSSON, G. (1998): Efficiency of early testing in Pinus sylvestris L. grown under two different spacings in growth chamber. Silvae Genet. 47(5-6): 298-306.

Jonsson, A., Eriksson, G., Ye, Z. H. and YeH, F. C. (2000): A retrospective early test of Pinus sylvestris seedlings grown at wide and dense spacing. Can. J. For. Res. 30: 1443-1454.

Karlsson, B., Mari, S. and ERIKSson, G. (2002): Juvenilemature genetic correlations in Picea abies (L.) Karst. under different nutrient and mycorrhiza regimes. Silvae Genet. 51(4): 171-175.

Kremer, A., Lascoux, D. M. and Nguyen, A. (1991): Morphogenetic subdivision of height growth and early selection in maritime pine. Proceedings of the $21^{\text {st }}$ Southern Forest Tree Improvement Conference, Knoxville, TN, USA, p. 203-221.

Kremer, A. and XU, L. A. (1989): Relationship between firstseason free growth components and later field height growth in maritime pine (Pinus pinaster). Can. J. For. Res. 19(6): 690-699.

LASCoux, D. M., Dormling, I. and KREMER, A. (1992): Germination and phenology of 1-year-old maritime pine (Pinus pinaster Ait.) seedlings under continuous light. Trees $\mathbf{7}$ $48-58$.

Lascoux, D. M., Kremer, A. and Dormling, I. (1993a): Growth and phenology of 1-yr-old maritime pine (Pinus pinaster) seedlings under continuous light: implications for early selection. Can. J. For. Res. 23(7): 1325-1336.

Lascoux, D. M., Paino, E. N., Sierra-De-Grado, R., Kremer, A. and Dormling, I. (1993b): Maturation of maritime pine (Pinus pinaster Ait.) seedlings after exposure to a period of continuous light. Tree Physiol. 12(4): 363-378.

LI, B., McKeand, S. E. and Allen, H. L. (1991): Seedling shoot growth of loblolly pine families under two nitrogen levels as related to 12-year height. Can. J. For. Res. 21(6): 842-847.

Lowe, W. J. and VAN-BuiJTENEN, J. P. (1989): The incorporation of early testing procedures into an operational tree improvement program. Silvae Genet. 38(5-6): 243-250.

Mari, S., Jonsson, A., Thompson, D. and Eriksson, G. (2002): Variation in nutrient utilization and juvenile growth in openpollinated families of Picea sitchensis (Bong.) Carr. grown in a phytotron and correlations with field performance. Silvae Genet. 51(5-6): 225-232.

Matheson, A. C., Spencer, D. J. and Kriedemann, P. E. (1995): Age-age correlation and early selection in radiata pine. I. Family $\mathrm{x}$ environment interactions in plantation and greenhouse. Aus. For. 58(2): 35-43.

Nguyen, A., Dormling, I. and Kremer, A. (1995): Characterization of Pinus pinaster seedling growth in different photo- and thermoperiods in a phytotron as a basis for early selection. Scan. J. For. Res. 10(2): 129-139.

SAS-INSTITUTE (1990): SAS Procedures guide, Version 6, Third Edition. SAS Institute Inc., Cary, NC, 705 p.

Sonesson, J., JAnsson, G. and ERIKsson, G. (2001): Retrospective genetic tests of Pinus sylvestris L. in growth chambers with two irrigation regimes and two temperatures. Scan. J. For. Res. 16(1): 21-29.

SonEsson, J., JANSSON, G. and ERIKSson, G. (2002): Retrospective genetic testing of Picea abies under controlled temperature and moisture regimes. Can. J. For. Res. 32(1): 81-91.

WaXler, M. S. and Van-BuiJtenen, J. P. (1981): Early genetic evaluation of Loblolly pine. Can. J. For. Res. 11: 351-355.

WiLliams, C. G. (1987): The influence of shoot ontogeny on juvenile-mature correlations in loblolly pine. For. Sci. 33(2): 411-422.

WiLliams, C. G. (1988): Accelerated short-term genetic testing for loblolly pine families. Can. J. For. Res. 18: 1085-1089.

WRICKE, G. (1962): Über eine methode zur erfassung der ökologischen streubreite in feldversuchen. Zeitung für Pflanzenzüchtung 47: 92-96.

Wu, H. X. (1998): Study of early selection in tree breeding. 1. Advantage of early selection through increase of selection intensity and reduction of field test size. Silvae Genet. 47(2-3): 146-155.

WU, H. X. (1999): Study of early selection in tree breeding. 2 . Advantage of early selection through shortening the breeding cycle. Silvae Genet. 48(2): 78-83.

Wu, H. X., Yeh, F. C., Dhir, N. K., Pharis, R. P. and Dancik, B. P. (1997): Genotype by environment interaction and genetic correlation of greenhouse and field performance in Pinus contorta ssp. latifolia. Silvae Genet. 46: 170-175.

ZAS, R. and FERNÁNDEZ-LÓPEZ, J.: Juvenile genetic parameters and genotypic stability of Pinus pinaster Ait. open-pollinated families under different water and nutrient regimes. For. Sci. (under revision).

Zas, R., Merlo, E. and Fernández-López, J. (2004): Genetic parameter estimates for Maritime pine in the Atlantic coast of North-west Spain. For. Genet. 11 (1): in press.

Zas, R., Merlo, E. and Fernández-López, J.: Genotype x environment interaction in Maritime pine families in Galicia, Northwest Spain. Silvae Genet. (under revision). 